\title{
Microsatellite based genetic diversity and mitochondrial DNA D-Loop variation in economically important goat breeds of Pakistan
}

\author{
A.N. Naqvi ${ }^{a, *}$, J.F. Bukhari ${ }^{\text {b }}$, S.M.F. Vahidi ${ }^{c}$, Y.T. Utsunomiya ${ }^{d}$, J.F. Garcia ${ }^{d}$, \\ Masroor Ellahi Babar ${ }^{\mathrm{e}}$, Jian-Lin Han ${ }^{\mathrm{f}}$, Rudolf Pichler ${ }^{\mathrm{g}}$, Kathiravan Periasamy ${ }^{\mathrm{g}}$ \\ a Faculty of Life Sciences, Karakoram International University, Gilgit Baltistan, Pakistan \\ ${ }^{\mathrm{b}}$ National University of Science and Technology, Islamabad, Pakistan \\ ${ }^{c}$ Agricultural Biotechnology Research Institute of Iran \\ d UNESP - Univ, Estadual Paulista, Faculdade de Medicina Veterinária de Araçatuba, Araçatuba, São Paulo 16050-680, Brazil \\ e Virtual University, Lahore, Pakistan \\ ${ }_{\mathrm{f}}$ CAAS-ILRI Joint Laboratory on Livestock and Forage Genetic Resources, Institute of Animal Science, Chinese Academy of Agricultural Sciences (CAAS), \\ Beijing, China \\ ${ }^{g}$ Animal Production and Health Laboratory, Joint FAO/IAEA Division of Nuclear Techniques in Food and Agriculture, International Atomic Energy Agency, \\ Vienna, Austria
}

\section{A R T I C L E I N F O}

\section{Article history:}

Available online 21 December 2016

\section{Keywords:}

Microsatellite

Genetic diversity

Pakistani goat

Mitochondrial control region

\begin{abstract}
A B S T R A C T
The present study was undertaken to analyze the genetic diversity of five economically important goat breeds of Pakistan, Beetal, Kaghani, Teddy, Nachi and Pahari. Fifteen microsatellite loci recommended by ISAG/FAO guidelines were investigated for measures of genetic variability, differentiation and population structure. The genetic variability in terms of allelic diversity and heterozygosity were moderate. The estimated inbreeding coefficient was low in all the investigated goat breeds and not significant. Overall, the populations were less diverse than Eurasian goat breeds, but did not exhibit signs of loss of diversity. Analysis of molecular variance (AMOVA) showed breed differences accounted for $5.42 \%$ of total genetic variation indicating low to moderate genetic differentiation among the investigated goat breeds. The genetic structure analysis revealed Teddy, Pahari, and Nachi as distinct breeds, while Beetal and Kaghani form a single genetic group distinct from the other three goats. The mitochondrial DNA control region sequences showed a total of 60 distinct haplotypes belonging to two major maternal lineages $\mathrm{A}$ and B1 with a frequency of $76.9 \%$ and $23.1 \%$ respectively. Comparison of mtDNA sequences from Pakistani, Indian and Iranian goats indicated distinct evolutionary history for Teddy, Beetal, Nachi and Pahari goats different from that of Indian and Iranian goats.
\end{abstract}

(c) 2017 International Atomic Energy Agency. Published by Elsevier B.V. All rights reserved.

\section{Introduction}

Pakistan is one of the largest goat rearing countries in the world following China and India with a population of 64.9 million, 182.9 million and 162 million respectively (FAOSTAT, 2014). During the last two decades, the population of goats in Pakistan has increased by more than $75 \%$ from 36.97 million in 1991-64.9 million in 2013 with an annual growth rate of 3.4\% (Afzal and Naqvi, 2004; Khan et al., 2008; FAOSTAT, 2014). The goat production system in Pakistan is mostly extensive, low external input type and is dependent on grazing alone or with provision of some available fodder during certain seasons. Most of the goats in Pakistan are owned by

\footnotetext{
* Corresponding author.

E-mail address: annaqvi@yahoo.co.uk (A.N. Naqvi).
}

smallholders with the flock size ranging from 6 to 15 . About $70 \%$ of goats are distributed in flocks with size less than 50 while remaining goats are distributed in flocks of bigger size i.e. about 50-200 animals or more (Khan et al., 2008). One of the most important characteristics of Pakistani goat breeds, as compared with those from other geographic locations, is their adaptation to harsh production environments such as dry climate, poor quality forage, water shortage, high altitude and temperature extremes. Thirty-six goat breeds have been described in Pakistan (Afzal and Naqvi, 2004; Khan et al., 2008), and the most important ones in terms of population size, economic value and production indices are Beetal, Dera Din Panah, Teddy, Barbari, Kamori, Kaghani, Nachi and Pahari (Naqvi, 2006). Although goat is an important animal resource in the rural setup of Pakistan, some of the breeds are threatened with a relatively large risk of extinction in near future. Among all available goats, the population trend is available for only ten breeds, of which pop- 
ulation status of five breeds were found to be declining (Khan et al., 2008). Specific studies targeting the assessment of genetic diversity in Pakistani goat populations are very limited despite their importance in the livelihood of local livestock keepers (Sultana et al., 2003; Hussain et al., 2013). Assessment of genetic diversity and relationships among different goat breeds is essential to make decisions on conservation priorities (Ajmone-Marsan et al., 2014). The present study was undertaken to assess the genetic diversity, population structure and phylogeography of five economically important indigenous Pakistani goat breeds using microsatellite and mitochondrial DNA markers. The resulting information can be used in formulating national plans and strategies for sustainable improvement and conservation of these breeds in Pakistan.

\section{Materials and methods}

\subsection{Animals and samples}

To know the present diversity status of five Pakistani goat breeds (Beetal, Kaghani, Teddy, Nachi and Pahari), an intensive field survey was carried out in the most representative agro-ecological zones of Pakistan. Basically, Pakistan is divided into ten agro-ecological zones based on physiography, climate, land use and water availability namely, Indus Delta, Southern Irrigated Plain, Sandy Desert, Northern irrigated Plain, Barani (rainfall), Wet Mountains, Northern dry mountains, Western Dry Mountains, Dry western Plateau and Sulaiman Piedmont (FAO, 2004; Pakistan Agricultural Research Council (PARC), http://www.parc.gov.pk/index.php/en/ component/content/article/43-maps/19-agrimaps). The field survey for the present study was conducted in Barani Lands (Teddy), Northern Irrigated Plains (Beetal, Teddy) Wet Mountains (Kaghani), Sandy Desert (Nachi), Western Dry Mountains (Pahari) and Sulaiman Piedmont zones (Pahari), the regions where the investigated breeds are mostly distributed. Although all the five breeds are distributed in the Punjab province of Pakistan, Beetal, Teddy and Pahari are also available in Khyber Pukhtunkhwa, Azad Jammu and Kashmir and Sindh provinces respectively. Beetal is a large sized breed distributed more commonly in Khyber Pukhtunkhwa and Northern Punjab, mainly in the districts of Multan, Sahiwal, Lahore, Faisalabad, Sargodha, Jhang, Okara, Jhelum, Gujranwala, Gujrat and Sialkot (Supplementary Figure SF1). Kaghani is concentrated in the Kaghan Valley in the districts of Abbotabad, Mansehra, Kohistan and Swat of Punjab. Pahari is distributed commonly in Loralai in Balochistan and D.G. Khan in Punjab. Nachi breed is found in Bahawalpur, Multan, and Sahiwal districts of Punjab while Teddy, although, widespread in the Punjab province, is concentrated in the districts of Gujrat, Jhelum, Sargodha, Rawalpindi in the Punjab and Kotli and Maripur in Azad Kashmir (Isani and Baloch, 1996; Afzal and Naqvi, 2004). A map indicating the sampling locations is provided in supplementary Figure SF2 and a brief description of the five investigated goat breeds is presented in table ST1. For each breed, blood samples were collected from unrelated goats belonging to multiple flocks across different villages. The farmers were interviewed in detail to ascertain the unrelatedness of collected samples. Blood was collected from the jugular vein into EDTA containing tubes. DNA purification was performed using the salting out protocol (Miller et al., 1988) and samples were stored at $-20^{\circ} \mathrm{C}$ until further processing. In addition to collection of blood samples for DNA preparation, data on the morphology of individuals and breed characteristics were recorded. Further, information regarding the existing goat breeds, distribution patterns and production purposes were retrieved from local livestock officers and farmers (Supplementary Table ST1). The number of samples collected from each of the five goat breeds include: Beetal (43), Kaghani(34), Teddy (41), Nachi (37) and Pahari (40).

\subsection{Microsatellite genotyping}

The laboratory work flow consisted of (1) DNA purification, (2) DNA quality and quantity estimation by agarose gel electrophoresis and spectrophotometry, (3) PCR amplification using microsatellite primers, (4) PCR product visualization in agarose gel electrophoresis, (5) preparation of PCR product for multiplex genotyping using a capillary sequencer (ABI 3730 DNA Analyzer - Applied Biosystems), (6) electropherogram analysis using GeneMapper software (Applied Biosystems) for allele size estimation and (7) statistical analysis using different software packages. Fifteen ISAG/FAO recommended microsatellite markers for diversity analysis in goats were used: ILSTS029, ILSTS11, ILSTS005, BMS1494, MAF035, MAF70, SRCRSP3, BM1818, SPS113, INRA0132, CSRD247, OARAE54, ETH10, OARFCB20 and MCM527 (FAO, 2011).

\subsection{Sequencing mitochondrial DNA control region}

Mitochondrial DNA control region was amplified and sequenced in 77 goats belonging to the five investigated breeds (Beetal (32), Kaghani (9), Nachi (11), Pahari (10) and Teddy (15)). Additionally, 14 Pak-Angora goats were also sequenced. Thus, a total of 91 sequences from six Pakistani goat breeds were generated in the present study. Primers were designed to amplify $1607 \mathrm{bp}$ mitochondrial control region using online tool Primer 3 version 4.0 (http://bioinfo.ut.ee/primer3-0.4.0/). The primer sequences used were GTMT-F $5^{\prime}$ cagcagctagcaccattgaa $3^{\prime}$ and GTMT-R $5^{\prime}$ AAGCGAGGC GTTGTAAGCTA 3'. Polymerase chain reaction was performed in a total reaction volume of $20 \mu \mathrm{l}$ with the following cycling conditions: initial denaturation at $95^{\circ} \mathrm{C}$ for $15 \mathrm{~min}$ followed by 30 cycles of $95^{\circ} \mathrm{C}$ for $1 \mathrm{~min}$; $60^{\circ} \mathrm{C}$ for $1 \mathrm{~min} ; 72^{\circ} \mathrm{C}$ for $1 \mathrm{~min}$ with a final extension at $72^{\circ} \mathrm{C}$ for $10 \mathrm{~min}$. Purified PCR products were sequenced using Big Dye Terminator Cycle Sequencing Kit (Applied Biosystems, USA) on an automated Genetic Analyzer ABI 3100 (Applied Biosystems, USA). In addition to 91 Pakistani goats, 69 sequences from five Iranian goat breeds (Abadeh (14), Khalkhali (15), Naini (15), Taleshi (12) and Turki-Ghashghaei (13)) generated from another study were included for comparative analysis. A $636 \mathrm{bp}$ control region sequence common to both Pakistani and Iranian sequence datasets that correspond to positions 15469-16104 of the complete mitochondrial genome (NCBI GenBank Accession No. GU229278) was utilized for estimating diversity and relationship among different breeds.

\subsection{Statistical analysis}

Measures of genetic variability including information on number of alleles, identification of private alleles, allele frequencies, allelic richness and observed and expected heterozygosities were obtained using GENEPOP software (Raymond and Rousset, 1995) available at http://genepop.curtin.edu.au/. Polymorphism information content (PIC) estimates were obtained using a customized Perl script, following methodology described by Botstein et al. (1980). GENEPOP was also used for the calculations of within-population inbreeding $\left(F_{I S}\right)$ (Wright, 1951) and exact tests of heterozygote excess and deficit for each marker and each breed. Pairwise estimations of $F_{S T}$ and $R_{S T}$ were obtained using the SPAGeDi 1.3 software (Hardy and Vekemans, 2002). The effective number of migrants between pairs of breeds per generation $\left(\mathrm{N}_{\mathrm{m}}\right)$ was calculated based on private alleles and corrected for sample size using GENEPOP. Inter-individual allele sharing distances were obtained using MICROSATELLITE ANALYZER (MSA) version 3.15 (Dieringer and Schlötterer, 2003). The neutrality of the microsatellites used in this study was evaluated by comparing the markers against neutral expectations in a distribution of $F_{S T}$ vs. heterozygosities under an island model of migration using LOSITAN version 1 for Linux 
Table 1

Number of observed alleles ( $\mathrm{n}_{\mathrm{o}}$ ), polymorphism information content (PIC) and private alleles (PA) with frequency (in parenthesis) in five Pakistani goat breeds.

\begin{tabular}{|c|c|c|c|c|c|c|c|c|c|c|c|c|c|c|c|}
\hline \multirow[t]{2}{*}{ Locus } & \multicolumn{3}{|c|}{ Beetal } & \multicolumn{3}{|c|}{ Kaghani } & \multicolumn{3}{|c|}{ Teddy } & \multicolumn{3}{|c|}{ Nachi } & \multicolumn{3}{|c|}{ Pahari } \\
\hline & $\mathrm{n}_{\mathrm{o}}$ & PIC & PA & $\mathrm{n}_{\mathrm{o}}$ & PIC & PA & $\mathrm{n}_{\mathrm{o}}$ & PIC & PA & $\mathrm{n}_{\mathrm{o}}$ & PIC & PA & $\mathrm{n}_{\mathrm{o}}$ & PIC & PA \\
\hline BMS1494 & 4 & 0.533 & - & 3 & 0.425 & - & 5 & 0.536 & $289(0.066)$ & 4 & 0.55 & - & 4 & 0.677 & - \\
\hline MAF035 & 2 & 0.274 & - & 2 & 0.175 & - & 2 & 0.255 & - & 2 & 0.305 & - & 2 & 0.262 & - \\
\hline SRCRSP3 & 5 & 0.652 & - & 5 & 0.566 & $117(0.065)$ & 4 & 0.636 & - & 5 & 0.642 & - & 5 & 0.554 & - \\
\hline BM1818 & 8 & 0.722 & - & 8 & 0.714 & - & 8 & 0.83 & - & 7 & 0.681 & - & 8 & 0.797 & - \\
\hline ILSTS029 & 8 & 0.509 & $163(0.012)$ & 6 & 0.355 & $183(0.016)$ & 5 & 0.515 & - & 4 & 0.522 & - & 6 & 0.354 & - \\
\hline OARFCB20 & 8 & 0.709 & - & 6 & 0.714 & $119(0.016)$ & 8 & 0.688 & - & 5 & 0.485 & - & 4 & 0.654 & - \\
\hline SPS113 & 7 & 0.677 & $159(0.012)$ & 5 & 0.676 & - & 4 & 0.562 & - & 5 & 0.606 & - & 6 & 0.641 & $153(0.013)$ \\
\hline CSRD247 & 6 & 0.63 & - & 6 & 0.767 & - & 5 & 0.726 & - & 4 & 0.648 & - & 9 & 0.725 & $\begin{array}{l}238(0.013), \\
244(0.064), \\
246(0.064)\end{array}$ \\
\hline ETH10 & 4 & 0.324 & - & 4 & 0.435 & $211(0.016)$ & 4 & 0.68 & - & 3 & 0.31 & - & 4 & 0.395 & - \\
\hline ILSTS011 & 5 & 0.38 & - & 5 & 0.657 & - & 6 & 0.707 & $281(0.014)$ & 3 & 0.568 & - & 5 & 0.382 & - \\
\hline INRA0132 & 3 & 0.13 & - & 5 & 0.326 & - & 6 & 0.336 & $155(0.132)$ & 3 & 0.155 & - & 5 & 0.519 & $145(0.128)$ \\
\hline MAF70 & 11 & 0.771 & - & 12 & 0.777 & $\begin{array}{l}152(0.032) \\
160(0.016)\end{array}$ & 6 & 0.676 & - & 6 & 0.468 & - & 10 & 0.783 & - \\
\hline ILSTS005 & 3 & 0.451 & - & 3 & 0.427 & - & 5 & 0.583 & $\begin{array}{l}186(0.026) \\
188(0.026)\end{array}$ & 3 & 0.413 & - & 3 & 0.36 & - \\
\hline MCM527 & 8 & 0.668 & - & 6 & 0.731 & - & 8 & 0.794 & - & 6 & 0.678 & - & 7 & 0.775 & $172(0.026)$ \\
\hline OARAE54 & 9 & 0.675 & $122(0.014)$ & 6 & 0.712 & $114(0.019)$ & 7 & 0.734 & - & 6 & 0.742 & - & 9 & 0.786 & - \\
\hline Mean & 6.1 & 0.540 & $3^{*}$ & 5.5 & 0.564 & $7^{*}$ & 5.5 & 0.617 & $5^{*}$ & 4.4 & 0.518 & $0^{*}$ & 5.8 & 0.578 & $6^{*}$ \\
\hline
\end{tabular}

${ }^{*}$ Total number of private alleles.

(Antao et al., 2008). A Bayesian clustering analysis was employed using STRUCTURE version 2.2 (Pritchard et al., 2000), which inferred fractions in genetic ancestry of individuals and populations assuming a given number $(\mathrm{K})$ of clusters. A Monte Carlo Markov chain was run for $K=2$ to 7 with a burn-in period of 200,000 and a run length of 200,000 iterations. An admixture model with noncorrelated allele frequencies was used and for each $\mathrm{K}$, ten runs were performed to identify the optimal K. To identify the optimal ' $\mathrm{K}$ ', the second order rate of change in $\mathrm{L}(\mathrm{K})$ with respect to different ' $K$ ' was calculated by following the procedure of Evanno et al. (2005). As a second approach for breed clustering, principal components analysis (PCA) was performed using SPSS version 10.5. Pairwise inter-individual allele sharing distances among the investigated Pakistani goat breeds were utilized to perform PCA. Two dimensional scatter grams of the first three largest principal component scores was drawn to visualize the clustering of Pakistani goats.

Mitochondrial DNA sequences were edited using Codon Code Aligner version 3.7.1. Multiple sequence alignment was performed using MEGA version 5.01 (Tamura et al., 2011). Mitochondrial DNA diversity parameters including nucleotide diversity, haplotype diversity, average number of nucleotide differences were calculated using DnaSP, version 4.10 (Rozas, 2009). The mitochondrial haplotypes of Pakistani goats were analyzed after including reference sequences for each of the six goat maternal lineages as suggested by Naderi et al. (2007). Median Joining (MJ) network of mtDNA haplotypes was constructed using NETWORK 4.5.1.2 (Bandelt et al., 1999). To further establish the evolutionary relationship of Pakistani and Iranian goats with goat populations of India, 366 mitochondrial DNA control region sequences from nine breeds and one non-descript local population (AY155674-AY156039; Joshi et al., 2004) were included for analysis. The final dataset included a total of 526 sequences ( 91 sequences from six Pakistani breeds; 69 sequences from five Iranian breeds and 366 sequences from ten Indian breeds/populations). A 369 bp mtDNA control region common to all the three (Pakistani, Iranian and Indian) datasets, corresponding to positions $15736-16104$ of the complete mitochondrial genome (NCBI GenBank Accession No. GU229278) was utilized to estimate pairwise $F_{S T}$ and analysis of molecular variance (AMOVA). Frequency of different haplotypes, haplotype sharing, AMOVA and pairwise $F_{S T}$ were estimated using ARLEQUIN 3.1 (Excoffier et al., 2005). Pairwise $F_{S T}$ derived from mtDNA haplotype frequency were utilized to perform principal components analysis using SPSS version 13.0.

\section{Results and Discussion}

\subsection{Genetic variability in Pakistani goat breeds}

The polymorphism information content and allelic diversity of Pakistani goat breeds at 15 microsatellite loci are presented in Table 1 . The mean polymorphism information content varied from 0.518 (Nachi) to 0.617 (Teddy) across different breeds. Genetic markers with PIC values less than 0.25 are considered to be less informative and those with values more than 0.5 are reckoned as distinctly informative in population genetic studies (Botstein et al., 1980). In the present study, ten microsatellite loci were observed to be highly informative (PIC $>0.50$ ) and five were moderately informative $(0.25<$ PIC $\leq 0.50)$ (Table 1$)$. The mean observed number of alleles varied from 4.4 (Nachi) to 6.1 (Beetal) among different goat breeds. Among different loci, allelic diversity was lowest at MAF035 locus while it was highest at MAF70 locus (Table 1). The mean allelic richness was estimated as 5.60, 5.39, 5.31, 4.25 and 5.45 in Beetal, Kaghani, Teddy, Nachi and Pahari breeds respectively. Private alleles were observed in all the Pakistani goat breeds studied except Nachi goats. The private alleles were observed at a maximum of six microsatellite loci in Kaghani, four loci in Pahari and three loci in each of Beetal and Teddy goats. The mean observed number of alleles in Paksitani goats were comparable to the reports in native Thai (Anothaisinthawee et al., 2012) and Malaysian (Marini et al., 2014) goats while it was much lower than Indian (Rout et al., 2008), Iranian (Vahidi et al., 2014), European and Middle Eastern (Cañón et al., 2006), Turkish (Bulut et al., 2016), Nigerian (Murital et al., 2015; Awobajo et al., 2015) and North African (Elbeltagy et al., 2016) goats.

The genetic variability in terms of observed and expected heterozygosity is presented in Table 2 . The mean observed heterozygosity ranged from 0.540 (Beetal) to 0.612 (Teddy) and the mean expected heterozygosity ranged from 0.549 (Nachi) to 0.640 (Teddy). No evidence of significant excess or deficit of heterozygosity was observed in any of the goat breeds studied, but loci BMS1494 and INRA0132 showed heterozygote deficiency $(\mathrm{P}<0.050$ and $\mathrm{P}<0.001$, respectively). It also needs to be noted that the allelic diversity and heterozygosity were the lowest at MAF035 among all 
Table 2

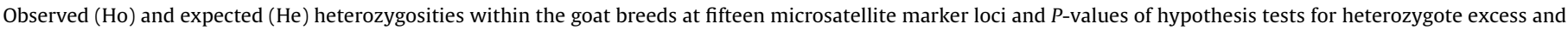
deficit.

\begin{tabular}{|c|c|c|c|c|c|c|c|c|c|c|c|c|}
\hline \multirow[t]{2}{*}{ Microsatellite } & \multicolumn{2}{|l|}{ Beetal } & \multicolumn{2}{|c|}{ Kaghani } & \multicolumn{2}{|l|}{ Teddy } & \multicolumn{2}{|l|}{ Nachi } & \multicolumn{2}{|l|}{ Pahari } & \multirow[t]{2}{*}{ Excess } & \multirow[t]{2}{*}{ Deficit } \\
\hline & Ho & $\mathrm{He}$ & Ho & $\mathrm{He}$ & Ho & $\mathrm{He}$ & Ho & $\mathrm{He}$ & Ho & $\mathrm{He}$ & & \\
\hline BMS1494 & 0.463 & 0.572 & 0.406 & 0.478 & 0.421 & 0.604 & 0.694 & 0.576 & 0.590 & 0.712 & NS & * \\
\hline MAF035 & 0.366 & 0.333 & 0.219 & 0.198 & 0.263 & 0.305 & 0.389 & 0.380 & 0.231 & 0.315 & NS & NS \\
\hline SRCRSP3 & 0.707 & 0.704 & 0.563 & 0.594 & 0.605 & 0.674 & 0.667 & 0.693 & 0.692 & 0.620 & NS & NS \\
\hline BM1818 & 0.854 & 0.734 & 0.813 & 0.728 & 0.842 & 0.844 & 0.722 & 0.693 & 0.795 & 0.816 & NS & NS \\
\hline ILSTS029 & 0.537 & 0.519 & 0.406 & 0.361 & 0.447 & 0.523 & 0.583 & 0.529 & 0.333 & 0.359 & NS & NS \\
\hline OARFCB20 & 0.756 & 0.750 & 0.719 & 0.754 & 0.737 & 0.719 & 0.500 & 0.561 & 0.692 & 0.694 & NS & NS \\
\hline SPS113 & 0.610 & 0.693 & 0.656 & 0.700 & 0.500 & 0.599 & 0.806 & 0.665 & 0.590 & 0.686 & NS & NS \\
\hline CSRD247 & 0.463 & 0.639 & 0.844 & 0.787 & 0.737 & 0.738 & 0.556 & 0.658 & 0.744 & 0.735 & NS & NS \\
\hline ETH10 & 0.220 & 0.365 & 0.500 & 0.488 & 0.763 & 0.719 & 0.306 & 0.362 & 0.487 & 0.499 & NS & NS \\
\hline ILSTS011 & 0.439 & 0.398 & 0.719 & 0.654 & 0.684 & 0.701 & 0.500 & 0.579 & 0.462 & 0.387 & NS & NS \\
\hline INRA0132 & 0.098 & 0.139 & 0.219 & 0.336 & 0.342 & 0.342 & 0.167 & 0.158 & 0.410 & 0.525 & NS & ${ }^{* *}$ \\
\hline MAF70 & 0.878 & 0.785 & 0.781 & 0.766 & 0.553 & 0.686 & 0.528 & 0.477 & 0.744 & 0.795 & NS & NS \\
\hline ILSTS005 & 0.537 & 0.517 & 0.500 & 0.484 & 0.737 & 0.649 & 0.417 & 0.511 & 0.487 & 0.401 & NS & NS \\
\hline MCM527 & 0.634 & 0.711 & 0.813 & 0.750 & 0.789 & 0.811 & 0.806 & 0.703 & 0.795 & 0.769 & NS & NS \\
\hline OARAE54 & 0.537 & 0.618 & 0.469 & 0.612 & 0.763 & 0.687 & 0.556 & 0.691 & 0.641 & 0.697 & NS & NS \\
\hline Mean & 0.540 & 0.565 & 0.575 & 0.579 & 0.612 & 0.640 & 0.550 & 0.549 & 0.580 & 0.601 & - & - \\
\hline
\end{tabular}

NS $=$ not significant.

${ }^{*} \mathrm{P}<0.05$.

$* \mathrm{P}<0.01$

*** $\mathrm{P}<0.001$

the loci analyzed. This locus had been reported to be under directional selection in Iranian goats (Vahidi et al., 2014) and potentially associated with a QTL for carcass traits (percent lean in carcass and total fat) in sheep (Cavanagh et al., 2010). However, as the heterozygosity deficit was not statistically significant $(\mathrm{P}>0.05)$ and $F_{S T}$ outlier detection method revealed neutrality of all fifteen marker loci, MAF035 was retained for further analysis. The mean expected heterozygosity in the studied populations was lower than previously reported for Indian, (Rout et al., 2008; Radhika et al., 2015), Chinese Cashmere (Di et al., 2011), European and Middle Eastern (Cañón et al., 2006), North African (Elbeltagy et al., 2016), Turkish (Bulut et al., 2016) and Iranian (Vahidi et al., 2014) goats. However, the mean values are comparable to the reports on South East Asian goats (Thai native (Anothaisinthawee et al., 2012) and Malaysian (Marini et al., 2014)) and Nigerian goats (Murital et al., 2015) while much higher than Korean goats (Kim et al., 2002).

The mean estimated inbreeding coefficient $\left(F_{I S}\right)$ was 0.045 , $0.008,0.044,0.005$ and 0.036 in Beetal, Kaghani, Teddy, Nachi and Pahari breeds respectively. The estimated $F_{I S}$ was not significant $(\mathrm{P}>0.05)$ in all the goat breeds. The absence of heterozygote deficiency and lack of significant inbreeding in the present study are interesting. Although the information on effective population size of the investigated breeds are not available, the Pakistan Livestock Census (GOP, 2006; Khan et al., 2008) revealed a total population size of 4.214 million, 0.532 million, 13.42 million, 0.114 million and 0.404 million for Beetal, Kaghani, Teddy, Nachi and Pahari goats respectively. Interestingly, the estimated levels of inbreeding was lower in Kaghani $\left(F_{I S}=0.008\right)$ and Nachi $\left(F_{I S}=0.005\right)$ breeds whose population size was significantly lower than Beetal and Teddy, the relatively popular goats of Pakistan. The goat production system in Pakistan is predominantly small holder based with the flock size varying from six to fifteen (Khan et al., 2008). Generally, the breeding practices do not involve intensive selection for economic traits and the farmers exchange bucks across flocks to avoid inbreeding. The estimated level of inbreeding in Beetal goats obtained using microsatellite markers (4.5\%) is comparable to average inbreeding $(f=3.7 \%)$ estimated based on pedigree information (Khan et al., 2007). However, it needs to be mentioned that this pedigree based estimation was performed in an experimental farm located in Punjab province of Pakistan, unlike the present study in which samples from unrelated goats belonging to farmers' flocks were utilized. Nevertheless, the observed estimates of inbreeding in Pakistani goats based on a small panel of microsatellite markers need to be interpreted with caution due to a potentially weak association between pedigree inbreeding coefficients and molecular metrics as reported previously in some natural populations (Markert et al., 2004; Slate et al., 2004; Overall et al., 2005). The extent of association between inbreeding and heterozygosity seems to depend strongly on the degree of inbreeding and on its variance so that weak relationships tend to be found in populations with low levels of inbreeding and low variance (Pemberton, 2004; Slate et al., 2004). With regards to conservation breeding programs, it appears that measures based on codominant markers lead to comparable results when at least 100 microsatellite loci are typed (Baumung and Solkner, 2003).

\subsection{Genetic differentiation and population structure}

Analysis of molecular variance (AMOVA) showed breed differences accounted for $5.42 \%$ of total genetic variation while $94.58 \%$ of variance was due to individual differences within breeds. The pairwise $F_{S T}$ ranged from 0.025 (Kaghani-Beetal) to 0.081 (PahariNachi) among different goat breeds. Similarly, the pairwise $R_{S T}$ ranged from 0.017 (Kaghani-Nachi) to 0.112 (Pahari-Nachi), while pairwise genetic distance $D_{\mathrm{A}}$ varied from 0.067 (Kaghani-Beetal) to 0.133 (Teddy-Pahari) (Table 3). This indicated low to moderate genetic differentiation among the investigated goat breeds and was found to be comparable although slightly lower than Indian $\left(F_{S T}=0.0659\right.$; Rout et al., 2008), Iranian $\left(F_{S T}=0.062\right.$; Vahidi et al., 2014), European and Middle Eastern ( $F_{S T}=0.07$; Cañón et al., 2006) Chinese $\left(F_{S T}=0.063\right.$; Di et al., 2011), Turkish $\left(F_{S T}=0.075\right.$; Bulut et al., 2016), North African $\left(F_{S T}=0.071\right.$; Elbeltagy et al., 2016), Nigerian $\left(F_{S T}=0.077\right.$; Murital et al., 2015) and Malaysian (Marini et al., 2014) goats. The estimates of effective number of migrants per generation $\left(\mathrm{N}_{\mathrm{m}}\right)$ ranged from 0.75 (Nachi-Teddy) to 3.20 (Beetal-Kaghani), with an average of $2.04 \pm 0.75$ (Supplementary Table ST2). Among the five Paksitani goat breeds, the pairwise $F_{S T}$ of Pahari goats with all other breeds $(0.038-0.081)$ and pairwise $F_{S T}$ of Teddy goats with all other breeds $(0.040-0.069)$ were higher than other pairwise combinations. Similarly, the pairwise genetic distance $D_{A}$ estimates of Pahari (0.083-0.133) and Teddy (0.090-0.133) goats were higher indicating the distinctness of these two breeds. This is further evidenced by relatively lower $\mathrm{N}_{\mathrm{m}}$ estimates of these goats with other investigated breeds. 
Table 3

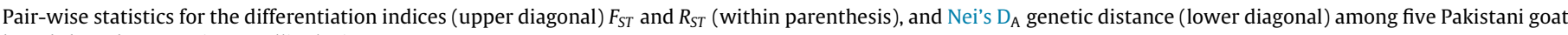
breeds based on 15 microsatellite loci.

\begin{tabular}{|c|c|c|c|c|c|}
\hline Breed & Beetal & Kaghani & Teddy & Nachi & Pahari \\
\hline Beetal & - & $0.025(0.019)$ & $0.044(0.021)$ & $0.057(0.037)$ & $0.050(0.063)$ \\
\hline Kaghani & 0.067 & - & $0.040(0.022)$ & $0.052(0.017)$ & $0.038(0.091)$ \\
\hline Teddy & 0.090 & 0.104 & - & $0.069(0.047)$ & $0.062(0.052)$ \\
\hline Nachi & 0.097 & 0.090 & 0.132 & - & $0.081(0.112)$ \\
\hline Pahari & 0.089 & 0.083 & 0.133 & 0.098 & - \\
\hline
\end{tabular}
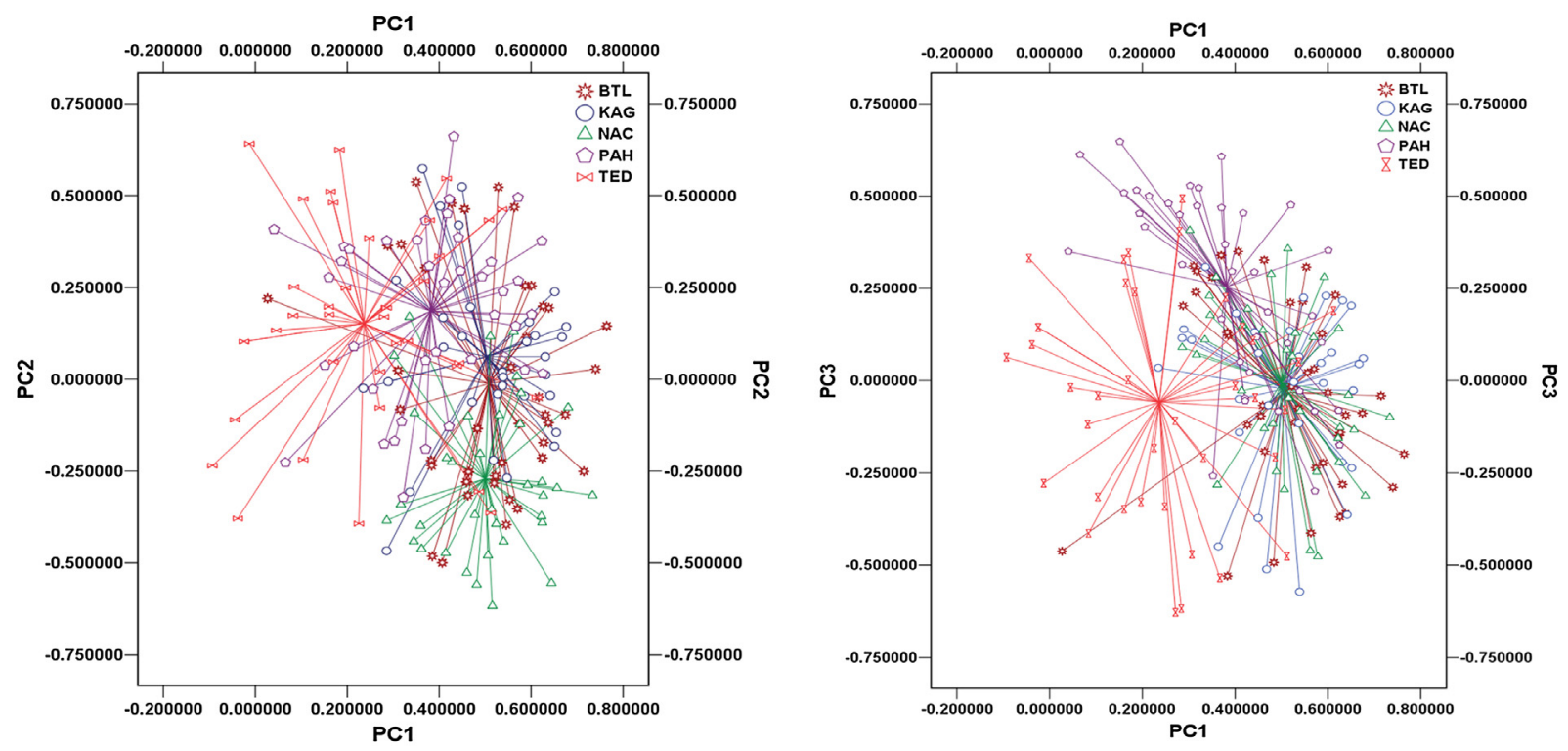

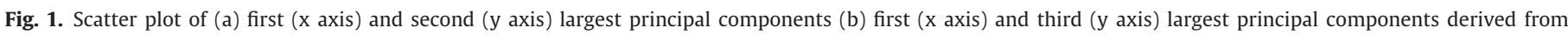

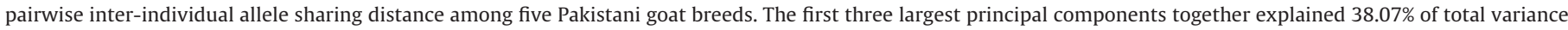
(PC1 = 21.24\%; PC2 = 8.98\%; PC3 = 7.85\%) (NAC-Nachi; BET-Beetal; PAH-Pahari; KAH-Kaghani and TED-Teddy).

Principal components analysis was performed to assess the genetic structure of studied goat breeds. The first three largest principal components together explained $38.07 \%$ of total variance with PC1 explaining $21.24 \%$ of the total variance followed by PC2 and PC3 with $8.98 \%$ and $7.85 \%$ respectively. The two dimensional scatterplot with the first and second largest principal components as axes showed distinct clustering of Teddy goats. Although the centroids of Pahari and Nachi goats were distinctly placed, overlapping of individuals from these breeds with Beetal and Kaghani goats was observed. Beetal and Kaghani were admixed completely and individuals from these breeds were not distinguishable (Fig. 1a). Further plotting of PC1 and PC 3 confirmed the distinctness of Teddy while Nachi was indistinguishable from Beetal and Kaghani. The centroid of Pahari was distinctly placed, but with considerable admixture between Beetal and Kaghani goats (Fig. 1b). Teddy and Pahari breeds were thus found to be relatively distinct from the three other goat breeds. Bayesian clustering of Pakistani goats with no a priori information on breed origin supported the findings of the principal components analysis. When $\mathrm{K}=2$ was assumed, most of the Teddy goats were assigned to first cluster, while Nachi and Pahari were assigned to second cluster. Significant admixture was found among Beetal and Kaghani goats with assignment of individuals from these breeds to both cluster 1 and 2 (Fig. 2). When $\mathrm{K}=3$ was assumed, most of the Teddy, Nachi and Pahari goats were distinctly assigned to three different clusters respectively. Complete admixture was observed with respect to the assignment of Beetal and Kaghani goats. The mean $\mathrm{L}(\mathrm{K})$ over 10 runs for each value of $\mathrm{K}$ was highest at $K=5$ (Fig. 3a). To identify the optimal $K$, the second order rate of change in $\mathrm{L}(\mathrm{K})$ i.e. delta $\mathrm{K}$ was estimated following the procedure of Evanno et al. (2005). $\Delta \mathrm{K}$ was based on the rate of change in the log probability of data between successive $\mathrm{K}$ values and has a mode at the true $K$. The results revealed $K=3$ as the optimal clustering solution for the given dataset (Fig. 3b) The results of PCA and STRUCTURE thus support the proposition that Teddy, Pahari and Nachi are genetically distinct breeds while Beetal and Kaghani are highly admixed goat populations with significant gene flow among them.

The genetic structure observed in Pakistani goats was broadly correlating with their geographical locations despite overlapping breed distribution and lack of significant barriers for gene flow. A similar observation of breed clustering conforming to geographical distance was reported in Indian goats reared under a similar kind of low external input small holder production system (Rout et al., 2008). On a wider spatial scale, Bayesian clustering analysis of European and Middle Eastern goats revealed $41 \%$ of between breed variations being attributed to geographic origin (Cañón et al., 2006). Gene flow among goat breeds would have been restricted most probably by geographical isolation and such restriction of genetic contacts might have caused geographical clines that predate breed formation (Canon et al., 2006; Lenstra et al., 2016). Thus, the findings on genetic structure of Pakistani goats in the present study will have significant implication in formulating strategy for conservation breeding. Teddy, Nachi and Pahari need to be maintained as purebreds, each with particular adaptations to their respective production environments, whereas crossing and continued admixture will not greatly affect the genetic make-up of Beetal and Kaghani goats.

\subsection{Mitochondrial DNA diversity and haplogroup classification}

A 636 bp sequence of mitochondrial DNA D-Loop region corresponding to positions 15469-16104 of the complete mitochondrial 


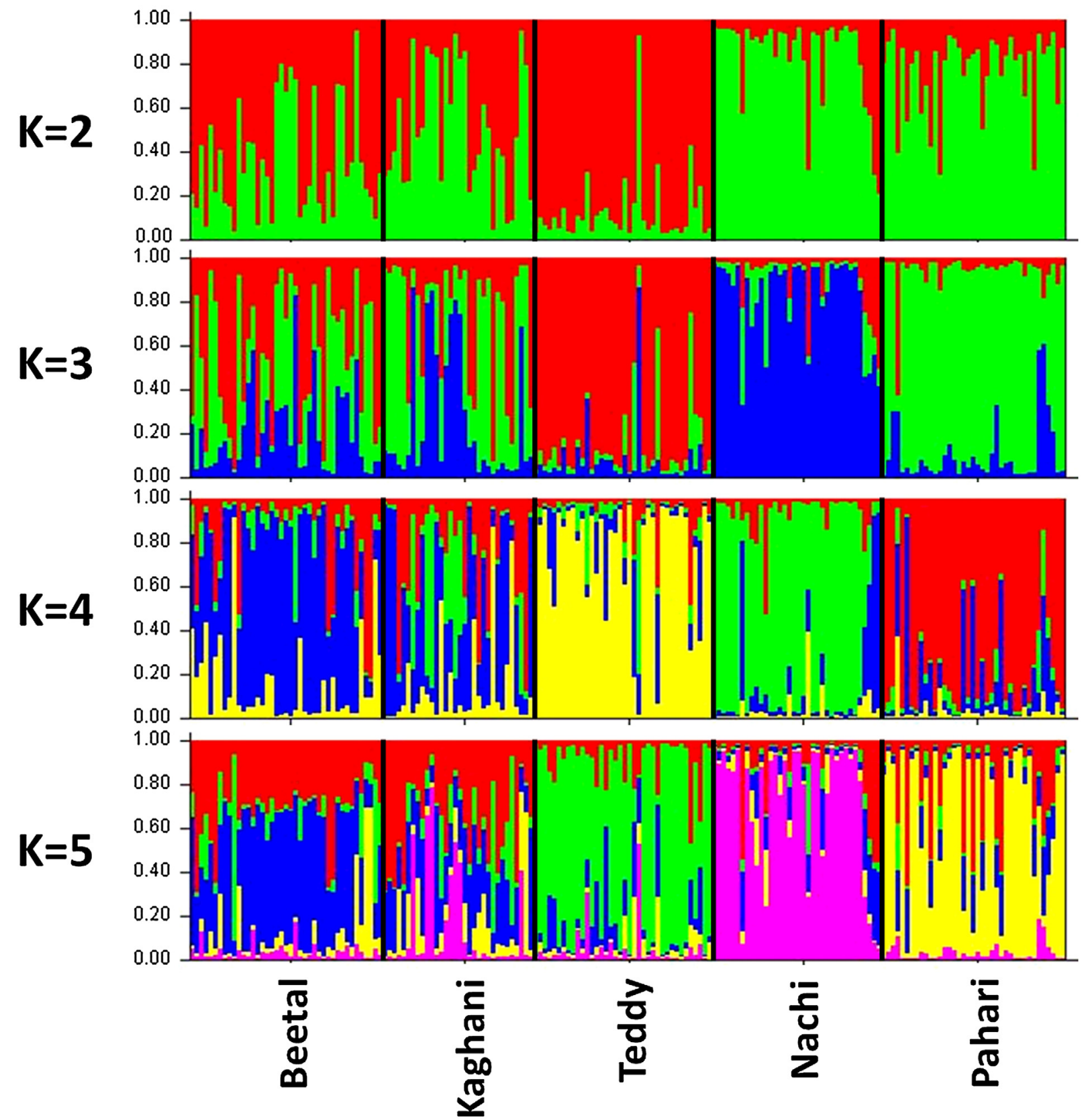

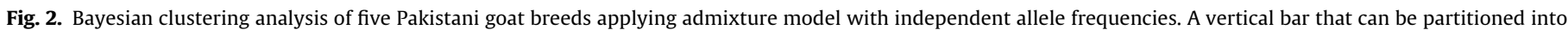

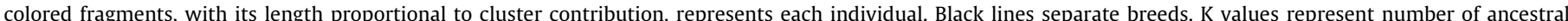
populations assumed.

Table 4

Mitochondrial DNA control region diversity within five Pakistani goat breeds.

\begin{tabular}{|c|c|c|c|c|c|c|c|c|}
\hline Breed & $\begin{array}{l}\text { No. Polymorphic } \\
\text { sites }\end{array}$ & $\begin{array}{l}\text { Parsimony } \\
\text { informative sites }\end{array}$ & $\begin{array}{l}\text { Nucleotide } \\
\text { diversity }\end{array}$ & $\begin{array}{l}\text { Average no. } \\
\text { nucleotide } \\
\text { differences }\end{array}$ & No. Haplotypes & $\begin{array}{l}\text { Haplotype } \\
\text { diversity }\end{array}$ & $\begin{array}{l}\text { Frequency } \\
\text { Haplogroup A }\end{array}$ & $\begin{array}{l}\text { Frequency } \\
\text { Haplogroup B1 }\end{array}$ \\
\hline Beetal & 62 & 50 & 0.030 & 18.78 & 20 & 0.944 & 0.688 & 0.312 \\
\hline Kaghani & 29 & 17 & 0.016 & 10.39 & 9 & 1.000 & 1.000 & 0.000 \\
\hline Nachi & 45 & 39 & 0.029 & 18.15 & 7 & 0.891 & 0.727 & 0.273 \\
\hline Pahari & 43 & 35 & 0.026 & 16.56 & 10 & 1.000 & 0.800 & 0.200 \\
\hline Teddy & 47 & 43 & 0.033 & 20.47 & 9 & 0.905 & 0.600 & 0.400 \\
\hline Pak Angora & 32 & 25 & 0.016 & 10.11 & 9 & 0.945 & 1.000 & 0.000 \\
\hline Overall & 72 & 61 & 0.028 & 17.22 & 60 & 0.971 & 0.769 & 0.231 \\
\hline
\end{tabular}

genome (NCBI GenBank Accession No. GU229278) was generated in 91 Pakistani goats belonging to six breeds. This included 77 sequences from five investigated goat breeds along with 14 sequences from Pak-Angora goats. All the sequences generated in the study were submitted to NCBI-GenBank and are available under accessions numbers KP671224-KP671314. The mitochondrial DNA 

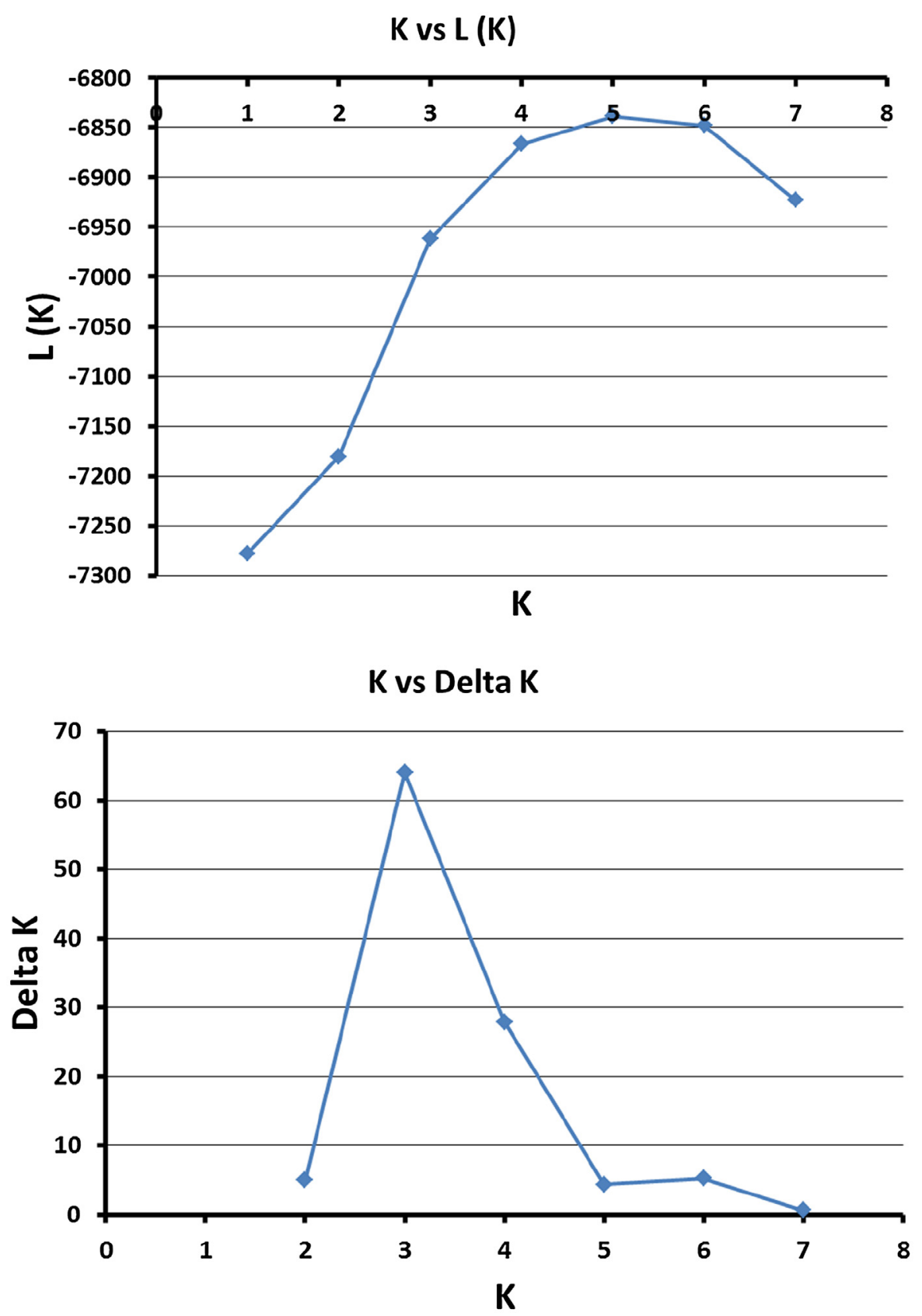

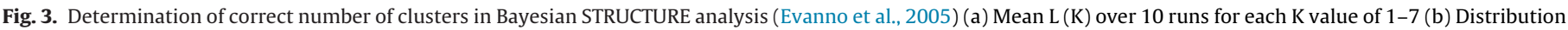
of $\Delta \mathrm{K}$ with the modal value $(\mathrm{K}=3)$ indicating the true $\mathrm{K}$ or the uppermost level of structure.

control region diversity in Pakistani goats is presented in Table 4. Overall, 72 polymorphic sites were observed of which 61 were parsimony informative sites. The nucleotide diversity varied from 0.016 (Kaghani and Pak-Angora) to 0.033 (Teddy). Similarly, the average number of nucleotide differences was lowest in Kaghani and Pak-Angora breeds while it was highest in Teddy breed. The overall haplotype diversity was 0.971 and ranged between 0.891 (Nachi) to one (Kaghani and Pahari). A total of 60 distinct haplotypes were observed with 20, 9, 7, 10, 9 and 9 haplotypes in Beetal, Kaghani, Nachi, Pahari, Teddy and Pak-Angora breeds respectively. The frequency of mitochondrial DNA haplotypes observed in Pakistani goat breeds is presented in Supplementary Table ST3. Most of the haplotype sharing was observed within breeds while only three haplotypes were shared among different breeds. Haplotype sharing between breeds included Beetal-Kaghani, Beetal-Teddy and BeetalNachi-Teddy respectively. Six major maternal haplogroups (A, B, C,
D, F and $G$ ) have been reported among domestic goats worldwide (Naderi et al., 2007). Haplogroup B included two sub-lineages B1 and B2 (Chen et al., 2005). Identification of haplogroups in Pakistani goats revealed two major maternal lineages A and B1. Haplogroup A was predominant with a frequency of $76.9 \%$ while haplogroup B1 occurred with a frequency of $23.1 \%$. The frequency of haplogroup B was higher than reported in Chinese goats (Liu et al., 2009 (19.87\%); Wang et al., 2015 (8.4\%)) and 6\% among goats worldwide (Naderi et al., 2007). Among the investigated breeds, haplogroup B1 was not observed in Kaghani and Pak-Angora goats. Teddy had the highest frequency of haplogroup B1 (40\%) followed by Beetal (31.3\%), Nachi (27.3\%) and Pahari (20\%) goats. In contrast to the previous report on 38 mtDNA sequences across 13 Pakistani goat breeds (Sultana et al., 2003), we only observed haplotypes belonging to two haplogroups. Sultana et al. (2003) observed haplogroups C and D with a frequency of $5.3 \%$ and $7.9 \%$ respectively in addition to haplogroups 


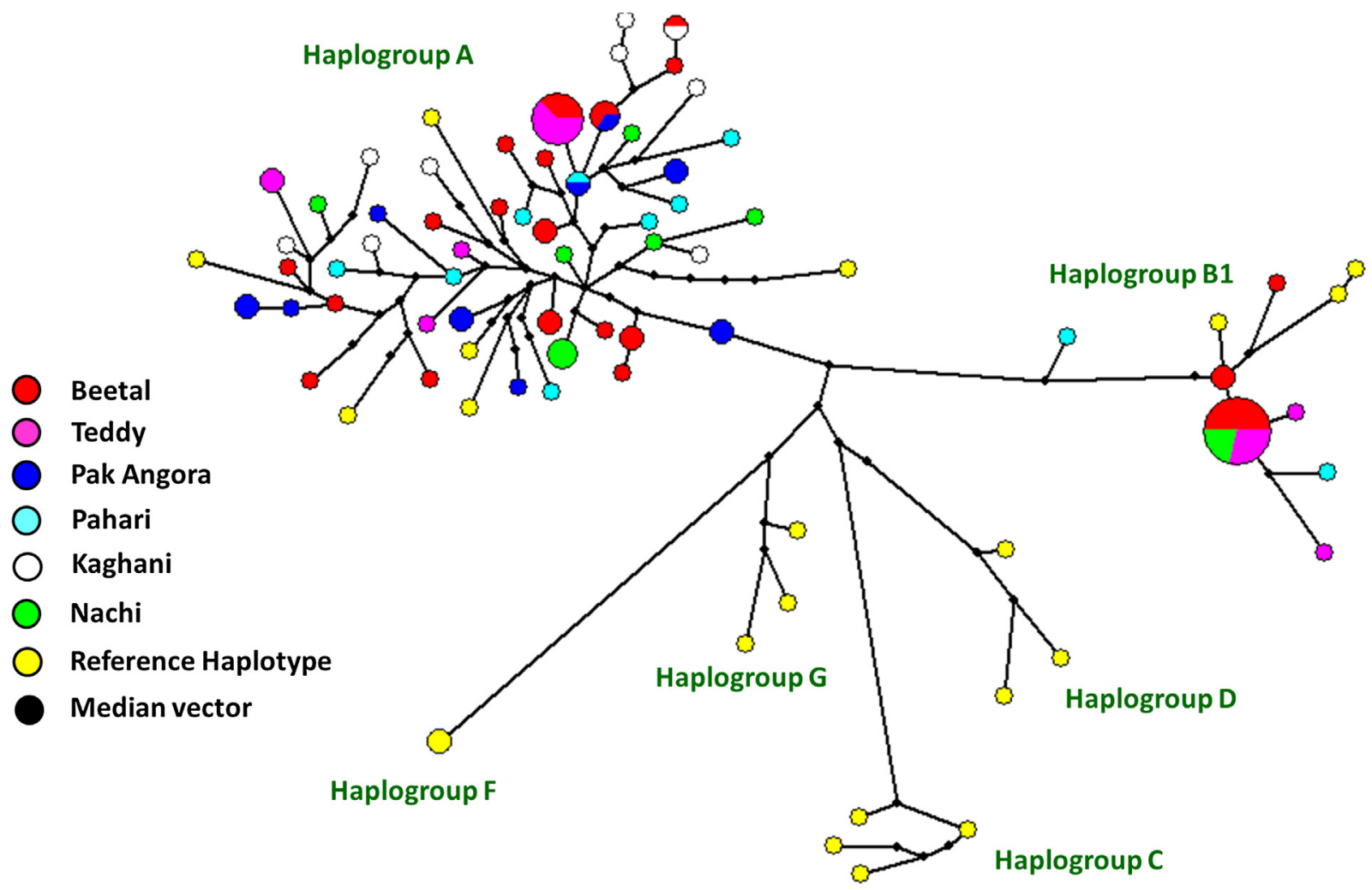

Fig. 4. Median Joining NETWORK of mtDNA control region haplotypes derived from Pakistani goat breeds and reference haplogroup sequences.

A and $B$, despite the sample size being smaller $(\mathrm{N}=38)$ but derived from a wider geographical area of four major provinces of Pakistan.

\subsection{Mitochondrial haplotype network and phylogeography}

Median Joining network of mtDNA haplotypes revealed two major clusters conforming to their haplogroup classification, i.e. haplogroup A and B1 (Fig. 4). All the reference sequences of haplogroups observed globally (A, B1, B2, C, D, F and G) (Naderi et al., 2007) were used to construct haplotype network. The haplogroup A cluster did not show any major clade/sub-clades in contrast to earlier reports (Doro et al., 2014; Colli et al., 2015). To further assess the evolutionary relationship with Indian goats, mtDNA D-loop sequences of 366 Indian goats belonging to 9 breeds and one nondescript population available at NCBI were used (Joshi et al., 2004). Further, goat mtDNA sequences from Iran bordering Pakistan in the west and part of early goat domestication center were also included in the analysis. Pairwise $F_{S T}$ derived from haplotype frequency was used to perform principal components analysis. The first three largest principal components explained $92.2 \%$ of total variance with PC1 explaining 56\% followed by PC2 and PC 3 explaining $23.2 \%$ and
$13 \%$ of the total variance respectively. Three dimensional scattergram of principal components revealed clustering of Indian and Iranian breeds along with Kaghani and Pak-Angora goats. Beetal, Teddy, Nachi and Pahari goats were clustering distinctly along with the local non-descript Indian (INLOC) goat population (Fig. 5). To further confirm the clustering pattern observed in PCA scattergram, analysis of molecular variance (AMOVA) was performed (Table 5). Among population variance was $5.43 \%$ when mtDNA sequences of Pakistani goat breeds alone were analyzed. It increased to $10.71 \%$ after inclusion of sequences from Indian and Iranian goats. When the breeds were grouped following PCA clustering, among group variance was $15.31 \%$ and significant $(P<0.05)$ while among population within group variance was $5.76 \%$. The results of AMOVA supported distinct clustering of Beetal, Teddy, Nachi and Pahari goats obtained by principal components analysis. Interestingly, all these four Pakistani goat breeds possessed B1 haplogroup with varying frequencies. Kaghani and Pak-Angora that possessed only haplogroup A clustered with Indian and Iranian goats. Indian goats were found to possess haplogroup A predominantly despite the presence of diverse haplogroups including B, C, D and E (Joshi et al., 2004). Sultana et al. (2003) observed a higher frequency of hap-

Table 5

Analysis of molecular variance (AMOVA) based on mtDNA control region haplotype frequency in five Pakistani goat breeds.

\begin{tabular}{|c|c|c|c|c|}
\hline Source of variation & Degrees of freedom & Sum of squares & Squared value & Percentage of variation \\
\hline \multicolumn{5}{|l|}{ No Grouping (Pakistani goats) } \\
\hline Among populations & 5 & 77.78 & 0.49 & 5.43 \\
\hline Within populations & 85 & 724.92 & 8.53 & 94.57 \\
\hline \multicolumn{5}{|c|}{ No Grouping (Pakistan-Iran-Indian goats) } \\
\hline Among populations & 20 & 367.13 & 0.56 & 10.71 \\
\hline Within populations & 505 & 2360.28 & 4.67 & 89.29 \\
\hline \multicolumn{5}{|c|}{ Grouping I (Pakistan-Iran-Indian goats) I-PKBTL, PKTED, PKPAH, PKNAC; II-All other Pakistani, Iranian and Indian goat breeds } \\
\hline Among groups & 1 & 120.17 & 0.91 & 15.31 \\
\hline Among populations within groups & 19 & 246.96 & 0.34 & 5.76 \\
\hline Within populations & 505 & 2360.28 & 4.67 & 78.94 \\
\hline
\end{tabular}




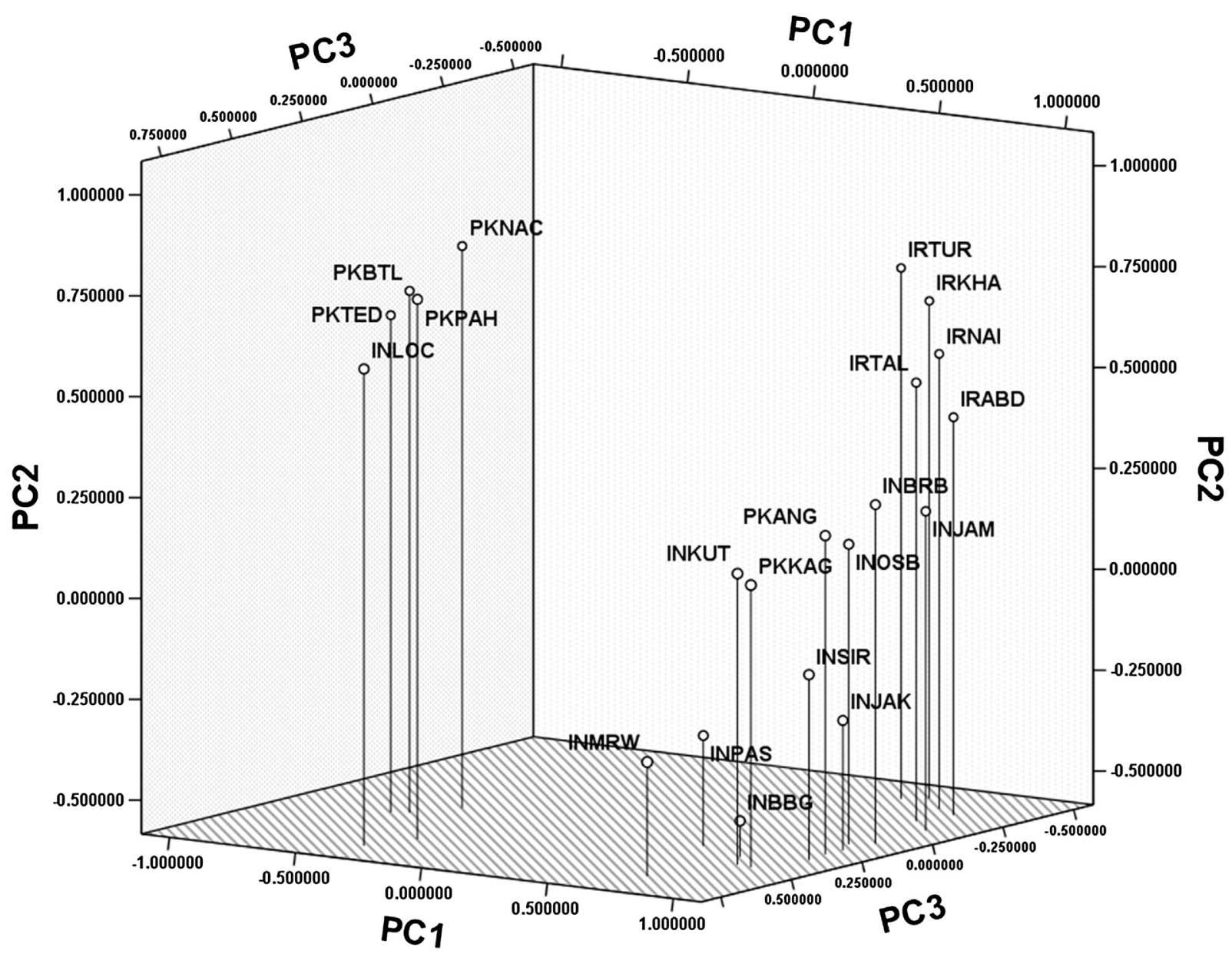

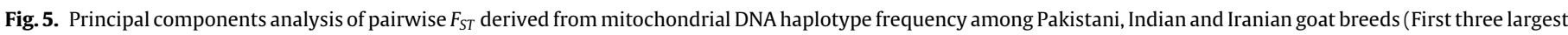

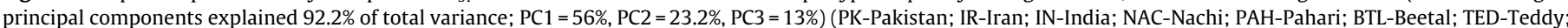

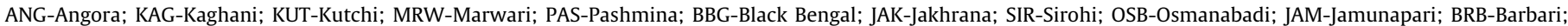
LOC-Local non-descript; TAL-Taleshi; NAI-Naini; ABD-Abadeh; KHA-Khalkhali, TUR-Turki-Ghashghaei).

logroup B in the northeastern area as compared to the southern area of Pakistan. Large scale analysis of mitochondrial DNA revealed worldwide predominant distribution of haplogroup A, while haplogroup B is restricted to eastern and southern Asia (Luikart et al., 2001; Naderi et al., 2007). Based on the results of mtDNA analysis, a distinct evolutionary history for Teddy, Beetal, Nachi and Pahari goats different from that of Indian and Iranian goats could be proposed. It is worth mentioning that three of these goat breeds were also genetically distinct when analyzed at 15 microsatellite loci in the present study. However, such a proposition need to be considered with caution as the sample size vary considerably among the investigated goat breeds and additional mtDNA sequences from these goats may help to provide further supporting evidences.

\section{Conclusions}

This work represents the first assessment of molecular genetic diversity of five economically important Pakistani goat breeds. The genetic variability in terms of allelic diversity and heterozygosity were moderate. The estimated inbreeding coefficient was low in all the investigated goat breeds and not significant. Overall, the populations were less diverse than Eurasian goat breeds, but did not exhibit signs of loss of diversity. The genetic structure analysis revealed that Teddy, Pahari, and Nachi as distinct breeds, while Beetal and Kaghani form a single genetic group distinct from the other three goats. The mitochondrial DNA control region sequences revealed two major maternal lineages $A$ and B1 with a frequency of $76.9 \%$ and $23.1 \%$ respectively. Comparison of mtDNA sequences from Pakistani, Indian and Iranian goats indicated distinct evolutionary history for Teddy, Beetal, Nachi and Pahari goats different from that of Indian and Iranian goats.

\section{Acknowledgements}

The authors thank the International Atomic Energy Agency (IAEA) for funding and technical support under the Coordinated Research Project (CRP) D3.10.25. The support provided by the International Livestock Research Institute(ILRI), Nairobi, Kenya and the CAAS-ILRI Joint Laboratory on Livestock and Forage Genetic Resources, Institute of Animal Science, Chinese Academy of Agricultural Sciences (CAAS), Beijing, China is gratefully acknowledged.

\section{Appendix A. Supplementary data}

Supplementary data associated with this article can be found, in the online version, at http://dx.doi.org/10.1016/j.smallrumres. 2016.12.031.

\section{References}

Afzal, M., Naqvi, A. N., 2004. Livestock resources of Pakistan: present status and future trends, Science Vision, 9, (1-2 \& 3-4), 1-14. 
Ajmone-Marsan, P., Colli, L., Han, J.L., Achilli, A., Lancioni, H., Joost, S., Crepaldi, P., Pilla, F., Stella, A., Taberlet, P., Boettcher, P., Negrini, R., Lenstra, J.A., Italian Goat Consortium, Econogene Consortium, Globaldiv Consortium, 2014. The characterization of goat genetic diversity: towards a genomic approach. Small Rumin. Res., in press http://dx.doi.org/10.1016/j.smallrumres.2014.06.010.

Anothaisinthawee, S., Oishi, T., Amano, T., Nomura, K., 2012. Genetic diversity and relationships between indigenous and the original Thai meat goat population based on microsatellite analysis. J. Anim. Genet. 40, 3-8.

Antao, T., Lopes, A., Lopes, R.J., Beja-Pereira, A., Luikart, G., 2008. Lositan: a workbench to detect molecular adaptation based on a $\mathrm{F}_{\mathrm{ST}}$-outlier method. BMC Bioinf. 9, 323

Awobajo, O.K., Salako, A.E., Osaiyuwu, O.H., 2015. Analysis of genetic structure of Nigerian West African Dwarf goats by microsatellite markers. Small Rumin. Res. 133, 112-117.

Bandelt, H., Forster, P., Rohl, A., 1999. Median Joining networks for inferring intraspecific phylogenies. Mol. Biol. Evol. 16, 37-48.

Baumung, R., Solkner, J., 2003. Pedigree and marker information requirements to monitor genetic variability. Genet. Select. Evol. 35, 369-383.

Botstein, D., White, R.L., Skolnick, M., Davis, R.W., 1980. Construction of a genetic linkage map in man using restriction fragment length polymorphisms. Am. J Hum. Genet. 32, 314-331.

Bulut, Z., Kurar, E., Ozsensoy, Y., Altunok, V., Nizamlioglu, M., 2016. Genetic diversity of eight domestic goat populations raised in Turkey. BioMed Res. Int. http://dx.doi.org/10.1155/2016/2830394, article ID 2830394.

Cañón, J., Garcia, D., Garcia-Atance, M.A., Obexer-Ruff, G., Lenstra, J.A. Ajmone-Marsan, P., Dunner, S., The ECONOGENE Consortium, 2006. Geographical partitioning of goat diversity in Europe and the Middle East. Anim. Genet. 37, 327-334.

Cavanagh, C.R., Jonas, E., Hobbs, M., Thomson, P.C., Raadsma, H.W., 2010. Mapping quantitative trait loci (QTL) in sheep. III. QTL for carcass composition traits derived from CT scans and aligned with a meta-assembly for sheep and cattle carcass QTL. Genet. Select. Evol. 42, 36.

Chen, S.Y., Su, Y.H., Wu, S.F., Sha, T., Zhang, Y.P., 2005. Mitochondrial diversity and phylogeographic structure of Chinese domestic goats. Mol. Phylogenet. Evol. 37 (3), 804-814

Colli, L., Lancioni, H., Cardinali, I., Olivieri, A., Capodiferro, M.R., Pellecchia, M., Rzepus, M., Zamani, W., Naderi, S., Gandini, F., Vahidi, S.M.F., Agha, S., Randi, E., Battaglia, B., Sardina, M.T., Portolano, B., Rezaei, H.R., Lymberakis, P., Boyer, F. Coissac, E., Pompanon, F., Taberlet, P., Marsan, P.A., Achilli, A., 2015. Whole mitochondrial genomes unveil the impact of domestication on goat matrilinea variability. BMC Genomics 16, 1115

Di, R., Farhad Vahidi, S.M., Ma, Y.H., He, X.H., Zhao, Q.J., Han, J.L., Guan, W.J., Chu, M.X., Sun, W., Pu, Y.P., 2011. Microsatellite analysis revealed genetic diversity and population structure among Chinese cashmere goats. Anim. Genet. 42 428-431.

Dieringer, D., Schlötterer, C., 2003. MICROSATELLITE ANALYSER (MSA): a platform indpendent analysis tool for larger microsatellite data sets. Mol. Ecol. Resources, 167-169.

Doro, M.G., Piras, D., Leoni, G.G., Casu, G., Vaccargiu, S., Parracciani, D., Naitana, S. Pirastu, M., Novelletto, A., 2014. Phylogeny and patterns of diversity of goat mtDNA haplogroup A revealed by resequencing complete mitogenomes. PLoS One 9 (4), e95969, http://dx.doi.org/10.1371/journal.pone.0095969.

Elbeltagy, A.R., Aboul-Naga, A.M., Hassen, H., Solouma, G.M., Rischkowsky, B., Mwacharo, J.M., 2016. Genetic diversity and structure of goats within an early livestock dispersal area in Eastern North Africa. Afr. J. Biotechnol. 15, 431-441.

Evanno, G., Regnaut, S., Goudet, J., 2005. Detecting the number of clusters of individuals using the software STRUCTURE: a simulation study. Mol. Ecol. 14, 2611-2620.

Excoffier, L., Laval, G., Schneider, S., 2005. Arlequin ver.3: 0: An integrated software package for population genetics data analysis. Evol. Bioinform. Online 1, 47-50.

FAO, 2004. Fertilizer use by crop in Pakistan. land and plant nutrition management service. In: Land and Water Development Division, Food and Agriculture Organization, Viale delle Terme di Caracalla 00100 Rome, Italy (Accessed on 18th May, 2015) ftp://ftp.fao.org/docrep/fao/007/y5460e/y5460e00. pdf.

FAO, 2011. Molecular genetic characterization of animal genetic resources. In: FAO Animal Production and Health Guidelines No. 9. FAO, Rome.

FAOSTAT, http://faostat fao.org/site/573/DesktopDefault.aspx?\#ancor, 2014

GOP(Gvernment of Pakistan), 2006. Pakistan Livestock Census 2006. Agriculture Census Organization, Statistics Division, Government of Pakistan, Lahore.

Hardy, O.J., Vekemans, X., 2002. SPAGeDi: a versatile computer program to analyse spatial genetic structure at the individual or population levels. Mol. Ecol. Notes 2, 618-620

Hussain, T., Babar, M.E., Sadia, H., Shaheen, M., Nadeem, A., Ali, A., Wajid, A., Shah, S.A., 2013. Microsatellite markers based genetic diversity analysis in Daman and Nachi goat breeds of Pakistan. Pakistan Veterinary Journal 33 (4), 520-522.

Isani, G.B., Baloch, M.N., 1996. Sheep and Goat Breeds of Pakistan. Press corporation of Pakistan, Karachi.
Joshi, M.B., Rout, P.K., Mandal, A.K., Tyler-Smith, C., Singh, L., Thangaraj, K., 2004. Phylogeography and origin of Indian domestic goats. Mol. Biol. Evol. 21 (3), 454-462.

Khan, M.S., Ali, A., Hyder, A.U., Chatta, A.I., 2007. Effect of inbreeding on growth and reproduction traits of Beetal goats. Arch. Anim. Breed. 50, 197-203.

Khan, M.S., Khan, M.A., Mahmood, S., 2008. Genetic resources and diversity in Pakistani goats. Int. J. Agric. Biol. 10, 227-231.

Kim, K.S., Yeo, J.S., Lee, J.W., Kim, J.W., Choi, C.B., 2002. Genetic diversity of goats from Korea and China using microsatellite analysis. Asian Aust. J. Anim. Sci. 15 461-465.

Lenstra, J.A., Tigchelaar, J., Biebach, I., Econogene Consortium, Hallsson, J.H Kantanen, J., Nielsen, V.H., Pompanon, F., Naderi, S., Rezaei, H.-R., Sæther, N., Ertugrul, O., Grossen, C., Camenisch, G., Vos-Loohuis, M., van Straten, M., de Poel, E.A., Windig, J., Oldenbroek, K., 2016. Microsatellite diversity of the Nordic type of goats in relation to breed conservation: how relevant is pure ancestry? J. Anim. Breed. Genet., http://dx.doi.org/10.1111/jbg.12226 (in press).

Liu, Y.P., Cao, S.X., Chen, S.Y., Yao, Y.G., Liu, T.Z., 2009. Genetic diversity of Chinese domestic goat based on the mitochondrial DNA sequence variation. J. Anim. Breed. Genet. 126, 80-89.

Luikart, G., Gielly, L., Excoffier, L., Vigne, J.D., Bouvet, J., Taberlet, P., 2001. Multiple maternal origins and weak phylogeographic structure in domestic goats. Proc. Natl. Acad. Sci. USA 98, 5927-5932.

Marini, A.A.B., Hifzan, R.M., Tan, S.G., Panandam, J.M., 2014. Assessment of genetic diversity on goat breeds in Malaysia using microsatellite markers. Malaysian J. Anim. Sci. 17, 19-26.

Markert, J., Grant, P.R., Grant, B.R., Keller, L.F., Coombs, J.L., Petren, K., 2004. Neutral locus heterozygosity, inbreeding and survival in Darwin's ground finches (Geospiza fortis and G. scandens). Heredity 92, 306-315.

Miller, S.A., Dykes, D.D., Polesky, H.F., 1988. A simple salting out procedure for extracting DNA from human nucleated cells. Nucleic Acids Res. 16, 1215.

Murital, I., Afolayan, O., Bemji, M.N., Dadi, O., Landi, V., Martinez, A., Delgado, J.V., Adebambo, O.A., Aina, A.B.J., Adebambo, A.O., 2015. Genetic diversity and population structure of Nigerian indigenous goat using DNA microsatellite markers. Archivos de Zootecnia 64, 93-98.

Naderi, S., Rezaei, H.-R., Taberlet, P., Zundel, S., Rafat, S.-A., Naghash, H.-R., El-Barody, M.A.A., Ertugrul, O., Pompanon, F., ECONOGENE Consortium, 2007. Large-scale mitochondrial DNA analysis of the domestic goat reveals six haplogroups with high diversity. PLoS One 2 (10), e1012, http://dx.doi.org/10. 1371/journal.pone.0001012.

Naqvi, A.N., 2006. Goat Genetic Resources in Pakistan. http://www.naweb.iaea.org/ nafa/aph/stories/2006-goat-genetic-pakistan.html.

Nei, M., Tajima, F., Tateno, Y., 1983. Accuracy of estimated phylogenetic trees from molecular data. J. Mol. Evol. 19, 153-170.

Overall, A.D.J., Byrne, K.A., Pilkington, J.G., Pemberton, J.M., 2005. Heterozygosity inbreeding and neonatal traits in Soay sheep in St Kilda. Mol. Ecol. 14, 3383-3393

Pemberton, J.M., 2004. Measuring inbreeding depression in the wild: the old ways are the best. Trends Ecol. Evol. 19, 613-621.

Pritchard, J.K., Stephens, M., Donnelly, P., 2000. Inference of population structure using multilocus genotype data. Genetics 155, 945-959.

Radhika, G., Raghavan, K.C., Aravindakshan, T.V., Thirupathy, V., 2015. Genetic diversity and population structure analysis of native and crossbred goat genetic groups of Kerala, India. Small Rumin. Res. 131, 50-57.

Raymond, M., Rousset, F., 1995. GENEPOP (version 1.2): population genetics software for exact tests and ecumenicism. J. Hered. 86, 248-249.

Rout, P.K., Joshi, M.B., Mandal, A., Laloe, D., Singh, L., Thangaraj, K., 2008. Microsatellite based phylogeny of Indian domestic goats. BMC Genet. 9, 11

Rozas, J., 2009. DNA sequence polymorphism analysis using DSP. Methods Mol. Biol. 537, 337-350.

Slate, J., David, P., Dodds, K.G., Veenvliet, B.A., Glass, B.C., Broad, T.E., McEwan, C., 2004. Understanding the relationship between the inbreeding coefficient and multilocus heterozygosity: theroretical expectations and empirical data. Heredity 93, 255-265.

Sultana, S., Mannen, H., Tsuji, S., 2003. Mitochondrial DNA diversity of pakistan goats. Anim. Genet. 34, 417-421.

Tamura, K., Peterson, D., Peterson, N., Stecher, G., Nei, M., Kumar, S., 2011. MEGA5: molecular evolutionary genetics analysis using maximum likelihood, evolutionary distance, and maximum parsimony methods. Mol. Biol. Evol. 28, $2731-2739$

Vahidi, S.M., Tarang, A.R., Naqvi, A.N., Anbaran, M.F., Boettcher, P., Joost, S., Colli, L. Garcia, J.F., Ajmone-Marsan, P., 2014. Investigation of the genetic diversity of domestic Capra hircus breeds reared within an early goat domestication area in Iran. Genet. Select. Evol. 46, 27.

Wang, G.Z., Pi, X.S., Ji, Z.B., Qin, Z.J., Hou, L., Chao, T.L., Wang, J.M., 2015. Investigation of the diversity and origins of Chinese dairy goats via the mitochondrial DNA D-loop. J. Anim. Sci. 93, 949-955.

Wright, S., 1951. The genetical structure of populations. Ann. Eugen 15, 323-354. 